\title{
THE BLUE YEARS: An Ethnography of a Prison
} Archive

\author{
ANGELA GARCIA \\ Stanford University \\ (D) http: / / orcid.org/0000-0002-6438-3771
}

In the spring of 2009, I visited Bernadette Martinez in the one-bedroom apartment that she shared with her mother and daughter. The last time we had seen each other was in the crowded visitation room of the women's prison where Bernadette had been an inmate. Recalling our conversation that day, Bernadette admitted that she hadn't yet done any of the things she said she would on her release, such as enroll in community college, get a job, maybe even join a gym. Although she laughed when she said this, she seemed distracted and sad. I suggested we get out of the apartment and take a drive somewhere, perhaps into the mountains. But Bernadette said no - it was too cold and she didn't want to be away when her daughter returned from school.

I first met Bernadette while conducting fieldwork on intergenerational heroin addiction in northern New Mexico. Bernadette's mother, Eugenia, had struggled with heroin addiction throughout Bernadette's childhood, and Bernadette began using the drug herself when she was a teenager. The splintering and repair of the Martinez household had been a focus of my ethnographic research, and I remained in touch with the family well after I completed the fieldwork that formed the basis of my book. At the time of my visit in 2009, I thought that the research phase of my relationship with Bernadette was over. In fact, a new phase of research was about to begin. This article tells the story of the emergence of this research and reflects on its implications for the writing of ethnography. It 
describes the creation of a prison archive and the ways it is productive for conceiving ethnography as a kind of archival endeavor that connects and unfolds affective, material, and temporal fields. The story begins with an exchange that occurred as I prepared to leave Bernadette's apartment that spring afternoon.

I was already at the door when Bernadette asked me to wait - she wanted to give me something. I watched as she disappeared into the bedroom she shared with her daughter, only to reemerge moments later with a large cardboard box. She carried it easily and asked me to store it for her, explaining that she didn't want the contents around her any longer, but didn't want to lose them either. Sensing my reluctance to say yes, Bernadette set the box on the floor and ripped off the tape that sealed its worn edges. She reached inside and pulled out handful after handful of paper, and let it fall at her feet. "They're just letters," she said. "Nothing illegal, nothing to worry about." Bernadette had been a patient at the drug detox clinic where I once worked as an ethnographer and staff member, and where I had witnessed her being subjected to drug searches. Standing above the box, letters spread before us, I had the feeling that we were back in the clinic and that she was being searched again. I helped Bernadette gather up the letters and place them back inside the cardboard box. We said goodbye and I took the box back home with me to California, for what Bernadette called "safekeeping."

For several months the box sat undisturbed in my office. Then one morning I opened it, only partly by accident. The first letter I drew out was undated. Written by Bernadette and addressed to Eugenia, it reads, "As long as you keep writing back I'll be OK. Pero los días que no me escribes se sienten lonely. Se sienten azules [But the days you don't write me feel lonely. They feel blue].” Bernadette's description of waiting and longing assumed the form of a haunting image - the image of lonely days, blue days. It was an image that carried excruciating affective and representational intensity for, to write the letter, Bernadette needed to purchase the blue-tinted paper from the prison commissary. At about five cents per sheet, writing was expensive; she earned less than twenty dollars a month working six-hour days. In this sense, the blueness of days seemed more than a melancholic account of Bernadette's interior world. It was also a manifestation of the carceral economy that structured her writing of despair.

Toward the end of the same letter, Bernadette asks about her daughter and tells Eugenia, "Cuídala bien, mamá. Cuídate bien [Take good care of her, mom. Take care of yourself]." She closes with, "I know you can't come. But send me a little something so I can buy paper, stamps, a phone card. . . . Please don't forget about me." 
I wanted to read more letters, felt I shouldn't, but did. After my period of passionate reading, I called Bernadette to admit to her what I had done. Multiple phone messages went unanswered. Eventually, I flew to Albuquerque and made the familiar drive north, to the Española Valley. After a couple of unsuccessful trips to Bernadette's apartment, I finally found her inside, the letters far from her mind.

\section{CORRESPONDENCE}

This article offers an ethnographic account of an archive of prison letters written by three generations of women: Bernadette, her mother Eugenia, and Bernadette's daughter, Ashley. It describes my engagement with the archive, which is a product of my ongoing ethnographic trajectory in New Mexico, and my relationship with the authors of the letters. In narrating this encounter, I record the context through which the letters emerged, as well as the desires, preoccupations, and practices that transformed them into an archive. A particular focus is the ways in which dislocation and connection manifest themselves in the letters and shape the kinds of narratives the archive tells. Isolation, loss, and forgetting constitute the thematic core of many of the letters, all of which take place within a wider context of social and political history. The function of ethnography, as I see it here, is to integrate narrative, history, and analysis to open up questions about social life. To this end, the story of the archivization of the letters helps pull together and frame these threads. ${ }^{1}$

The process by which I have come to preserve, organize, and study the letters is neither direct nor simple. I am not trained in archival methods, so I use the term archive with some reservation. But the idea of the archive lies at the heart of this ethnographic project because I am concerned with the materiality of the letters (Bennett 2010; Stoller 2015), the processes and spaces of their preservation (Steedman 2002), and the way they sit within historiography (Stewart 1996). These are all defining features of archival work, and they are clearly visible in institutions of memory where archivists work. They are generally less visible within marginalized or excluded communities where stories are often told through supposedly ordinary sites, such as correspondence between kin (Burton 2005). Yet these are precisely the sites that serve as evidence of, and work against, historical erasure.

Writing about her efforts to create a postcolonial digital archive with her Indigenous friends in Australia, Elizabeth Povinelli $(2011,149)$ asks, "When we evoke the archive, what are we conjuring by way of inclusion and exclusion? 
What, for instance, is the difference between an archive and a collection or between an archive and a hoard or between an archivist and a collector and a hoarder?" These are the sorts of questions that I have also asked while thinking about the kind of relationship I might establish with the letters Bernadette entrusted to me. Indeed, Bernadette posed a similar question once when she asked me to define archive, a term she was unfamiliar with. It was shortly after I had admitted to her that I had read the letters, and I was excited by the idea of organizing them into an archive. How quickly I jumped from shame about having read the letters to excitement about structuring them! Bernadette's question served as a powerful reminder of how the materials and languages scholars use to build narratives that question unequal power relations are often products of that very process (Dirks 2002). I tried to answer her difficult question: what is an archive? It's like a place for things you want to save, I said. Not like the selfstorage units people rent (which were ubiquitous in the Española Valley), but more like a photo album. I recalled the plastic, wallet-shaped album that Bernadette had shared with me during her stay in detox. The photos were organized chronologically, beginning with a picture of Ashley swaddled in a hospital blanket and ending with an image of her at three or four years old, seated on Bernadette's lap. Most of the album's sleeves were empty.

What differentiates an archivist from a hoarder or a collector, Povinelli (2011, 151) suggests, is that she or he is charged to find "lost objects, subjugated knowledges, and excluded socialities." From this perspective, the letters become material remains that condense affective and social relations. As an ethnographic site of inquiry and a methodological praxis, conceiving the letters as an archive has helped me to explore the historicity and narrativization of these relations. Bodies of correspondence, especially letters written by and for kin, have long served as a source of historical records or knowledge-making. This article engages not only with letters but also with the authors who produced them. These ongoing and vital interactions limit the tendency toward closure and univocal meaning. Like Bernadette's photo album, the prison archive uncovers the singularities, preoccupations, and discontinuities of the correspondents' lives. In the sections that follow, I trace the social conditions and forces of desire through which the archive was constituted, and provide an analysis of how it embodies them on the levels of content and form.

Much of the critical analysis of the archive focuses on its role in the development of the modern liberal state (Derrida 1996; Joyce 1999). The spatial arrangements of archival institutions, and their role in constituting subjects and 
historical narratives, are key areas of inquiry (Bennett 1995; Dirks 2002; Foucault 2002; Mbembe 2002). But rather than embodying a monolithic discipline or ideology, the archive also constitutes a space of "promiscuous and mutually contaminating contiguity” (González Echevarria 1990, 153; see also Edwards 2001). Inscribed with counterdiscourses, the archive may open up the possibility of new historical narratives and modes of subjectivity that are not reducible to the power of the state. Such possibilities are explored in recent anthropological studies that call attention to the archive as a complex nexus of presence and absence, the intimate and the global, affect and aesthetics (Taylor 2003; Stoler 2009; Stevenson 2013; Zeitlyn 2012). They are also explored in feminist historiography that seeks to bring women's private experiences more fully into the purview of history and politics (Chaudhuri, Katz, and Perry 2010; Hemmings 2011; Dave 2012), and in diverse forms of scholarship concerned with the experience of people traditionally excluded from historical accounts, sometimes glossed as "history from below" (Dunbar-Ortiz 2014; Thompson 1966).

Building on these studies, I explore the archive of letters with the goal of shedding new light on the authors' arts of existence within the carceral system that characterizes law and ethical life in contemporary society (Foucault 1979; Rhodes 2001). I also read the letters as texts that embody the key meanings of loss and survival located at the heart of Hispano experience in northern New Mexico. ${ }^{2}$ On the level of ethnography, I attend to how these meanings are embedded in both the rhythms of daily living and in the longue durée of colonial history. I explore these different registers through the interplay of the letters' narrative elements and the archive's material production.

The prison archive is composed of more than three hundred letters. They begin in June 2005 and end in May 2008, although many are undated and may extend beyond this period. I do not know how many letters were lost or destroyed, underscoring the archive's fragmentary nature. Bernadette wrote most of the surviving letters, but there are a few dozen written to her by Eugenia and Ashley. Structured thematically rather than chronologically, this article focuses on a handful of letters between Bernadette and Eugenia, primarily because of the particular story these letters tell. The selection of some letters always involves the discounting of many more, including Ashley's letters, which are mostly drawings. Ashley's picture-letters raise important practical issues with regard to editing, transcription, and translation, which I am unable to discuss fully here. I should note, however, that I reproduce many features of manuscript originals (e.g., emphases, Spanish language, paragraph breaks). This is not to imply veri- 
similitude, but to provide interpretation and intertextual engagement with particular correspondences within the broader framework of ethnography. ${ }^{3}$

About half of the letters in the archive are written on the blue paper purchased from the prison commissary, with the other letters on white or yellow paper. Many of the pages are torn, creased from folding, or missing. All are handwritten, and Bernadette's sprawling script often proves difficult to read, especially during her periods of illness. There are envelopes too, almost all of which are addressed to Eugenia, who lived at three different addresses during Bernadette's period of incarceration. Bernadette had only one address during this time, and all of the letters addressed to her show evidence of inspection by prison officials, usually in the form of an institutional stamp or code. A housecleaner once mistook a portion of the letters I was studying for trash. Consequently, some of the letters exude the odor of rotting fruit.

"Nothing could be at once more intimate and more alienable," Terry Eagleton (1982, 54-55) writes; the letter is "part of the body which is detachable: torn from the very depths of the subject." Eagleton's metaphor of tearing resonates with my own ambivalence in being the keeper and curator of the archive. Indeed, I have struggled with the idea of writing about the letters, sharing a fear that Roland Barthes (2010, 23) describes as "making literature" out of private grieving. That this danger seems more threatening to me now-that is, when writing about the archive - than it did when I wrote about Bernadette and her family without reference to it, speaks to the kinds of "seductions" inherent in archival research (Freshwater 2003, 734). ${ }^{4}$ It also raises critical questions about the varying sensibilities we bring to different genres of ethnographic documentation and writing, and the different insights they enable (Biehl 2013; Clifford and Marcus 1986; Stewart 2012).

Over the years, I have written about Bernadette and her family without saying anything about the letters, feeling that a key resource for my thinking remained hidden from view. In these works, I give much attention to cultural, economic, and personal histories of dispossession and I draw, in part, on these histories to account for Bernadette's desire to preserve the letters. The letters make tangible connections between history, loss, and desire. I hope to show that they are not simply representations of this relationship but material traces of it. ${ }^{5}$

\section{THE ARCHIVAL SUBJECT}

I moved to northern New Mexico in 2003 to conduct fieldwork for my doctoral dissertation. For more than three consecutive years, I lived in a small 
village in the Española Valley, a rural network of villages that extend out of the present-day town of Española. For more than two decades, this economically depressed region has had one of the highest per capita rates of heroin addiction and heroin-induced death in the United States, a phenomenon that disproportionately affects the region's Hispano population (Garcia 2010). Among Hispanos, heroin addiction often exists across multiple generations of kin. I was born in New Mexico and have roots in the region. I returned there as an adult because I wanted to understand multigenerational heroin addiction and its relation to colonial history. A central focus of this work is the contrary potentialities of addiction, especially as they are realized within multigenerational households. Let me reflect on these potentialities briefly and consider how they are organized and haunted by a legacy of colonialism, for this legacy also bears on the archive.

The Española Valley was settled by Spanish families beginning in the seventeenth century through a system of land grants from the Spanish monarchy. Community grants provided individuals and families a small parcel of land on which to build a home, irrigate, and cultivate. The remainder of the grant consisted of a far larger parcel reserved for the common use and benefit of all settlers. ${ }^{6}$ During the time New Mexico formed part of Spain, and later part of Mexico, the community land grant was central to the creation and maintenance of affective, material, and social bonds. These bonds were radically disrupted following the loss of land tenure for Hispanos after the Mexican-American War (1846-1848), and deteriorated further under the economic and legal culture in Territorial New Mexico (Dunbar-Ortiz 2007). ${ }^{7}$ Yet within Hispano families, stories about "lost" or "stolen" lands survive and are passed down the generations. Sometimes these stories are accompanied by historical records related to them, such as property deeds, maps, and surveyor reports. These stories and records mobilize profound affective connections to a past that today's heirs can neither possess nor escape.

The multigenerational heroin-addicted household must be understood in this light, as it also contains a sedimented history of connection and disconnection. Indeed, addiction might be understood as the symbolic surrogate for, and memorial of, severed genealogical bonds that now reside within the addicted family bloodline (Garcia 2014). The affective and symbolic significance of this "property" transfer becomes especially apt in the way second- and third-generation heroinusers describe heroin addiction as la nueva querencia, the new inheritance. Addiction is an inheritance that animates past traumas, but also one that aims to keep connection alive and unfinished. 
The archive of prison letters offers another way to conceive of this history of rupture, displacement, and connection experienced by Hispano families. The letters I draw from in this article deal explicitly with these experiences, all of which take place within a wider historical context and the experience of carcerality. Yet the archive can be seen as an attempt to counteract the dislocation that results from these processes. Like the multigenerational heroin-addicted household, the archive is a site of tension between what is lost and what remains. As Liz Stanley (2004, 209) notes, "the letter exists because of the absence of the writer and the distance (literal or figurative) between them and the addressee." Considering its materiality, the letter leads us to think about how, as an object, it might signify the absence of something or someone else, and the relationship itself. By weaving together the content of the letters with an ethnographic account of archival practice, I hope to navigate the tensions the archive embodies. My goal is not to make a coherent narrative out of the letters, but to think through them as a genre of living that is at once unique to this particular family and also illuminates the realities of contemporary Hispano life. ${ }^{8}$

\section{DISLOCATION}

Excerpt from a letter to Eugenia

April 7, 2006

I am doing my best to keep my mind so it means a lot to know that you are doing ok. Everything is the same but I have blisters on my wrist. My skin hurts. I was upset at the c/o for not taking me to the infirmary. She ignores me everyday. I told her the yard had no shade and my skin was burning. I walked up to her and showed her my arms. She ignored me and looked the other way and I started yelling and waving me arms. I didn't hit her but my mind was saying STOP but I couldn't stop. She ignores me. I need my cream. Can you please let them know? PLEASE. She ziptied my hands behind my back. She made me sit in the yard even when everyone else was called inside. She separated me. I was afraid I would go to Level 5 because she threatened. I just had to sit in the sun like that for hours. Even though it was cold the sun burned.

I feel like I'm shouting and no one hears. It's hard to write because it hurts. I have to be honest with you. It bothers me my cellmate gets more visits from her family even though they live in Window Rock. I think that is further away. That's what she said but maybe she's just trying to get me. 
She seems pretty nice though. She reminds me of Piñon because she is so short and round. Why don't you come? You can ask Laura to give you a ride. Her sister is in Level 3 and I heard from Brenda who is here too that she comes at least once a month.

You are in my prayers. Please keep me in your prayers. Please don't forget me.

Bernadette was charged with a drug-related offense shortly before we met. Prior to her trial, she was court-ordered to the rural drug recovery program where I worked. My official job title was detox attendant, and I observed Bernadette's month-long stay during my work on the night shift. I also attended to her basic needs, like providing food and medication, or dialing the telephone for her outgoing calls.

Part of my job involved recording these activities in the clinic's daily log, a cheap spiral notebook with wide-ruled pages. Although detox attendants were directed to record everything that took place during their shift, the vast majority of entries merely recorded the time and offered neutral statements like "no unusual activity" or "all patients treated as indicated." I followed the lead of my coworkers and jotted down such statements, thinking as I wrote that the daily $\log$ revealed nothing of life in the clinic. On later reflection, what it did reveal was the highly constructed nature of the archive, whether through fabrication or omission. This is a point Carolyn Steedman $(1998,67)$ makes when she writes, "In the Archive, you cannot be shocked at its exclusions, its emptiness, at what is not cataloged" (see also Hull 2012). Far from being complete or trustworthy, the daily log remained empty. Yet it still constituted a source of power and authority in the clinic, and it confirmed these qualities, at least in theory, on the detox attendant charged with recording the day's events. From about six in the evening to six the following morning, I was that person.

Having been a patient at the clinic before, Bernadette was used to the routine of rehab. We talked casually in the evenings and sometimes late at night. From these conversations, I learned that Bernadette's mother was also addicted to heroin and suffered from depression, a condition that seemed to predate her drug use. Bernadette worried about Eugenia and often asked me to check in on her. From our talks, I also learned that Bernadette was the mother of a young daughter, Ashley, whom she clearly loved and deeply missed. She knew that she would not be reunited with her daughter after completing detox. Instead, she was legally 
confined to her trailer until her trial date, and Ashley was placed in the care of another relative before moving in with Eugenia.

I visited Bernadette regularly during that period and she told me stories about her life. Often these stories centered on "another time," when she and Eugenia lived in their ancestral village, in the ancestral home. Bernadette would have inherited it had Eugenia not sold it during a period of financial desperation. Bernadette spoke lovingly about the home, and often shared with me memories of the kind of occasions on which family photographs are usually taken. But there were very few photos that she could draw on in her narration, perhaps because of her other stories, such as her mother's addiction and depression, their worsening poverty, and her own deepening loneliness. The painful loss of the home was entangled with these stories, and with Bernadette's lonely confinement in the trailer.

After Eugenia sold the ancestral home, she left the village and moved with Bernadette into a rented trailer in town. This was in the late 1980s, a time when heroin was abundant in the Española Valley and health services were few. Eugenia and Bernadette thus crafted their own services by caring for each other. This often meant that Bernadette obtained heroin, or medicina (medicine), to relieve her mother's physical and emotional pain. During our conversations, Bernadette described the reparative nature of heroin in her relationship with her mother, how it nourished and sustained their connection, especially after they began using the drug together. "It brought us closer together," she said.

\section{MATERIALIZING MEMORY}

Excerpt from a letter to Eugenia

\section{Undated}

I hope you are OK. How's mi hita? I miss her so much. So much. So much. I am just trying to stay out of people's way so I can get back home. It's turning winter already. Sometimes I can smell firewood in my mind. Thanksgiving is coming. We're making decorations like we did when I was a kid, but they don't let us touch scissors. All the ladies are trying to make the best of it. What else can we do?

In 2005, Bernadette was sent to the state's women's prison in Grants, a former uranium-mining town that has come to rely on prison work. Several women I came to know during my research landed there, while others had relatives incarcerated there. Over time, the prison became a key site of inquiry for 
me. One of the correctional officers I interviewed, a single mother from Grants, described the challenge of working there. "It's a decent living. But my mom's inside and she don't deserve it." She went on to tell me that her mother "had a disease," that is, she was addicted to drugs. "Most of the inmates, they've got it, too. If they didn't have it, they'd probably be working here like me." Her comments speak to the exclusionary potential of addiction in a radically unequal world. The prison works to ensure this potential, the consequences of which are felt among inmates and their families alike. ${ }^{9}$

New Mexico's women's prison was established in 1989, a time of unprecedented growth within the U.S. prison system. ${ }^{10}$ It is the first privately run women's prison in the United States and is run by the Corrections Corporation of America, which contracts with state and county governments, as well as with U.S. Immigration and Customs Enforcement, to house inmates. In many cases, these contracts include so-called lock-up quotas - a guarantee that states will either provide a certain number of prisoners or pay for their empty beds. The contract for the New Mexico's women's prison includes a 95 percent occupancy quota, which it has never failed to meet. ${ }^{11}$ Currently, the prison holds more than six hundred women, with plans to add another two hundred beds. About 90 percent of its inmates are nonviolent drug offenders, two-thirds of whom have children.

Shortly after Bernadette's incarceration, a communications representative gave me a tour of the prison, accompanied by a male correctional officer. The prison is divided according to level of security risk, and I was permitted to see its minimum- and medium-security units. These units were subdivided into socalled pods that appeared to reflect and reinforce racial, ethnic, and religious hierarchies, as well as expectations for inmate performance. For example, the God Pod was a cell-free dormitory designed to "build the character" of women through religious training, support groups, and prayer. Unlike the other areas I visited, the God Pod had radios, televisions, microwave ovens, and other prized possessions made available through Christian ministries. In contrast, women assigned to the pod for mentally ill inmates, known as Loco Town, lived and ate in their cells alone and had restricted access to movement and visitors. ${ }^{12}$ When I asked the correctional officer where Bernadette resided, he replied "somewhere in between."

Although I visited Bernadette in prison, sent letters, and wired money at her request, I never received a letter from her. So I was surprised when I first saw her broad and looping script, how her words shifted back and forth from 
print to cursive, English to Spanish, fashioning an intimate, bilingual language that simultaneously increased and narrowed the distance between writer and addressee. For example, in a letter to Eugenia, she writes, "Por qué no me visitas? ¿por qué no aceptas mi llamada? Este silencio me preocupa tanto [Why don't you visit me? Why won't you accept my phone call? This silence worries me so much].” Then, switching to English, "I feel like shit. You haven't written in a long time. I think they have it out for me. Someone here doesn't like me. Or maybe you are forgetting me?"

On my last visit with Bernadette in prison, she was noticeably heavier and upset. She told me that she couldn't sleep and was anxious. Her mother and daughter hadn't written her back in a long time, and she worried that they had moved away without telling her. At the same time, she imagined that her mother was desperately trying to reach her through letters that were being interceptedby whom, she didn't know. She asked me to find out why the flow of letters had stopped. My first impulse was to write Bernadette more frequently, as if writing from me might ease her sense of isolation and anxiety. But I also worried that letters from me might exacerbate the absence of the writing she longed for.

Writing in the prison context, whether creative writing or letter writing, is often assumed to have intrinsic therapeutic value for inmates (Jacobi and Stanford 2014). The past decade has seen an increase in prison writing projects, as well as in creative writing programs for individuals in the "free community" wanting to teach writing behind bars (Bernstein 2010). Such efforts may be transformative for prisoners and instructors alike, and they may also be socially and political powerful, although it is unclear how such programs translate to the need for, and complexity of, large-scale prison reform. But the focus on creative writing, and the attendant possibility of the educability of inmate-writers, tends to ignore the unequal power relations and colonial discourses on which such initiatives are built. ${ }^{13}$

Like any genre or text, prison writing is far from self-evident and open to numerous functions and interpretations. By considering it outside of its specific location and following its dispersal though other sites, such writing can be more capaciously understood. My long-term ethnographic work in the Española Valley, and my engagements with Bernadette, have enabled me to recognize other stories and scenes that clustered around the recurring theme of unrequited communication in her prison letters. Leaking into and animating her worries about the possible interception of the letters were past experiences of separation and disconnection, including the loss of a beloved home, the precariousness that accom- 
panies being the daughter of an unstable mother, and the absence of the thing (heroin) that made connection to her mother (and, by extension, her daughter Ashley) possible. These moments seemed to collapse as Bernadette narrativized her feelings of displacement.

\section{Excerpt from a letter to Eugenia}

\section{Undated}

Nada hay nuevo debajo del sol [There's nothing new under the sun]. I'm just working and waiting. Every day the same day. I don't even know if I am even writing this to anyone anymore since I don't get anything back. When did I get to be so alone? When did you stop caring about me?

No se puede sacar agua de una piedra [You can't get water from a stone].

In this fragment, Bernadette draws on two Spanish dichos - sayings or proverbs rooted in Latino cultural and familial discourses. Cultural analyses of dichos tend to emphasize their pedagogical role in shaping normative behaviors and expectations (Espinoza-Herold 2007). However, in this context, these commonly told dichos become a mode of relating the emotional and temporal contours of Bernadette's life. The first dicho, nada hay nuevo debajo del sol, conveys a sense of repetition that constitutes life in prison, and likely extends beyond it. I interpret it as a repetition connected to Bernadette's growing loneliness, which she attributes to her unrequited letters. The second dicho, no se puede sacar agua de una piedra, seems to express Bernadette's deep disappointment with Eugenia's lack of response, which might be interpreted as a deficiency of maternal love and care. But this expression of disappointment, of surrender, might also be an invitation for her mother to respond, which she eventually does. ${ }^{14}$

\section{Letter to Bernadette}

January 2007

Mija,

I know you are angry. Ashley is too. It is a long way and the pressure on me is heavy. Juntas 2 o 3 veces a la semana. Estoy tratando de ganarse la vida. No seas duro conmigo mija [Two or three recovery meetings a week. I'm trying to get a hold on my life. Don't be so hard on me, my child]. 
I have a new job. It isn't much but I am hoping to buy us a car to make travel easier. You're so far. Hopefully you will be out soon right? That's what I hear.

No había celebraciones después de que murió mi madre . . por eso soy una mala madre. Lo siento [After my mother died there were no celebrations . . . that's why I'm a bad mother. I'm sorry]. Ashley knows she has a mother. It's not the same. She made a pretty card for you, it's very pretty and she can write now. I want to send it but you think you will not receive it so I am saving it for you for when you return. Unless you want me to send it.

Lo siento por todo el dolor mija. Me comprometo a escribir y visitar más. Fuerza! Siempre estás en mis pensamientos [I'm sorry for all of the pain, my child. I promise to write and visit more. Be strong! You are always in my thoughts].

\section{RELATING NARRATIVES}

Early in 2010, I returned to New Mexico to carry out research in the Department of Corrections Collection in the New Mexico State Archives, located in Santa Fe. The focus of my research was the Territorial Penitentiary, which was established in 1884. The penitentiary was one of several institutions, including the Indian School and the Insane Asylum, representing New Mexico's transition from Spanish colonial and Mexican systems of governance to an American one. At the time, I was broadly interested in the penitentiary's female inmate population, a preoccupation shaped by my relationship with Bernadette and the archive.

I spent a month in the state archive, reading materials associated with female inmates. These included intake reports containing demographic and sentencing information, warden reports, medical and punishment records, and digital scans of inmate photographs. From what I could gather, there were fewer than a hundred female inmates between 1885 and 1920, the majority of whom were young women of "Spanish" descent. A few of them were also described as "addicted to morphine" or "mentally insane." Most were mothers charged with property crimes or adultery. Significantly, adultery was considered a federal crime under the new legal system, and people of Spanish descent were typically married in the church, not in civil (i.e., legal) ceremonies. American legal authorities aggressively prosecuted New Mexico's "illegal inhabitants" (i.e., domestic partners not married in a civil union), ostensibly to improve their morals. As a result, many families were separated and their historic property claims delegitimated (Montoya 2002).

My time in the archive revealed striking parallels between Territorial-era inmates and today's prison population. Then as now, female inmates tended to 
be young, poor, and had children. They were often convicted of "crimes against morality" that carried lasting personal and economic consequences. The tragedies of the past seemed to extend into the present.

During my period of research in the state archive, I also began interviewing Bernadette about the prison letters. I wanted to understand the circumstances of writing, circulating, and preserving the letters, and the limits of what could be expressed and shared in the prison setting. In one of our interviews, Bernadette spoke about living in an environment that resounded with women talking, swearing, yelling, and crying. She recalled the sounds of metal doors clanging shut, keys jangling, alarms buzzing. While sitting in the quiet of the state archive, perusing the Corrections Collection, I often imagined her reading and writing in the midst of such noise.

In another interview conducted during the same period, Bernadette relayed the events surrounding the discovery of the letters, which occurred shortly after her release from prison. "They were under the bed," she recalled, "wrapped up in shopping bags, little piles of them.” Prior to this encounter, Bernadette didn't know that the letters she sent home had been saved. I asked if Eugenia had saved them, but Bernadette said no, it was Ashley, who hadn't yet learned to read. The revelation visibly pained Bernadette.

In her essay "The Melancholic Imagination,” Julia Kristeva (1987, 5) writes, "It is being separated from his mother, despairingly, with no going back, that prompts [the child's] attempts to recuperate her, along with other objects, in his imagination and, later, in words." From this psychoanalytic perspective, Ashley's safekeeping of Bernadette's letters from prison might represent her recuperation of her mother via words and dreams. This recuperation may have afforded Ashley sorrowful pleasure at a time of painful separation. But the letters also served as a witness to the loss enveloping her. By collecting and preserving the traces of her mother, Ashley was preparing the archive for itself, opening up a future for the history I write here.

As it turned out, Ashley wasn't the only one to recuperate and imagine, for Bernadette also saved many of the letters that Eugenia and, eventually, Ashley wrote to her. But as prisoners are only allowed to keep a limited number of personal items, Bernadette was forced to part with many of them to make room for new ones. Bodies of correspondence that work as relations and history were thus curtailed, pointing again to the inherently partial and political nature of any archive (Steedman 2002). In another interview conducted during this period of 
research, Bernadette described the fraught practice of sorting through letters and determining which ones she might part with:

I had two piles. One was letters I would trade in. They were old or maybe seemed unimportant. Or I memorized them and didn't think I needed them. . . . The other pile I wanted to keep no matter what. . . I I checked those two piles all the time. I worried I put one in the wrong place, you know, the wrong pile. Like I accidentally was getting rid of something that I really wanted to keep, and when I checked through the piles I was always changing my mind about the ones I thought I could get rid of because they all seemed important again.

Referring to the constant sorting and self-doubt, Bernadette described feeling like she was "going crazy." At the same time, the ritual of sorting may have been a means of preserving her lost connection, and perhaps even her mind.

After several months of anxious sorting, a more experienced cellmate suggested that Bernadette instruct family members to write on only one side of each sheet of paper, thereby leaving the other side blank. In this way, Bernadette could respond on the blank side, send the letter back, thereby saving precious money and, perhaps, both letters. But this epistolary practice raised different anxieties, such as whether her unstable mother would ever write to her, or keep the letters she hoped to preserve. (At the time she did not know her daughter was saving them.) Still, Bernadette tried this new method, so that many of the letters in the archive are in fact two.

In the shared gesture of writing and saving, narrative is always double narrative, and the relation between authorship, time, and emotion is entangled. Ashley's and Bernadette's appropriation of the archive expands the signifying capacities of language and endows new meaning and significance to these texts. I, the most recent curator of these letters, am implicated in this process too.

Shortly after my time in the state archive, I began my own process of sorting. I separated the letters by author, followed with several weeks of closely reading the three bodies of writing. While reading, I began identifying or extracting major themes. Initially these themes were motherhood, childhood, home, and prisontopics I was grappling with at the time. On subsequent readings, it became apparent that these categories were insufficient, even crude. I added addiction, distance, and depression, but neither did these categories capture the complex embodiment of history and emotion that adhered in the letters. The more I read, 
sifted, and pondered the letters, the more they seemed to exceed the limits of their thematic placement.

I called Bernadette a few times during this period with the intention of seeking her advice about how to organize the letters, but she had more pressing concerns. She couldn't find a full-time job, her relationship with her mother was tenser than usual, Ashley was struggling in school, and the man she was dating had a difficult ex-wife. When I finally managed to ask Bernadette about the letters, she cut me off and told me that I could "do whatever" I wanted with them. But I knew that wasn't true.

Eventually, I hired an undergraduate student to work as my research assistant, which I really didn't need. I'm not sure if I did this because I craved companionship in the process of archiving, or if I wanted the letters to acquire scholarly legitimacy, or perhaps both. In any event, the assistant's first task was to photocopy each letter three times. She neatly coded each duplicate in pencil based on the faulty chronological and thematic system I devised, and began filing the duplicates accordingly. Watching her handle the letters (that is, their duplicates), I grew panicky and possessive and soon had her do unrelated work. My feelings were stirred less by her misreading or misplacing the letters, but by her encountering them physically. It was as if the letters were alive, vulnerable to a stranger's touch.

Anthropological studies that explore the agency of objects open a line of inquiry on the affective dimensions and social relations that letters embody (Belting 2011; Gell 1998; Pinney 2001). The materiality of the archive can thus be explored as a confluence of these processes, and provide the basis for conceptualizing a tactile sense of history and sociality. These complex sensory responses to the letters are related to the way in which they have been dispersed through evolving social fields - from political histories of dispossession, the specific forces of dislocation and desire, and attenuated kinship ties to the actualities of daily life. ${ }^{15}$ These fields, and the constellation of scenes and narrations that accompany them, are embodied in the letters' sheer materiality. Extending beyond their textured surface, they give rise not to a precise explanation or narrative, but to a profound connection. It is the nature of this connection, and what it might mean for an ethnography of the prison archive, that I would like to explore in the final section. 


\section{ARCHIVING CONNECTION}

Writing about the forces that return him to Catarina, the protagonist of Vita, João Biehl $(2013,577)$ notes, "ethnographic subjects allow us to return to the places where thought is born." For Biehl, the return to Catarina constitutes more than his ongoing commitment to any one individual or site, but to the possibilities for thought that are opened up through time. The people and places that we circle back to in the ethnographic endeavor-hence in space, time, and writing - are critical practices integral to the making of new forms of knowledge. From this perspective, the work of return becomes a thought experiment, one that emphasizes new beginnings and futurity.

Bernadette also adopts the figure of return as a kind of impetus, but an impetus for something beyond thought. In nearly all of her letters to Eugenia, she asks for a response — don't forget me, write back, come and visit. The futurity of Bernadette's letters is thus oriented to the reply of the addressee, which inevitably entails a return to memory and loss. One letter to Eugenia makes this especially clear. Written midway into Bernadette's prison term, the letter begins with casual updates about her daily activities. Then the letter seems to turn with a critical realization:

Sometimes when I'm writing you I forget that you don't me write back. I forget that you CANT or WONT tell me a thing. I forget that I am the only one who hears me.

The letter then moves into the past and records a series of accusations, betrayals, and painful scenes that involve Bernadette and Eugenia. It also expresses the unfinished grief that accompanies them. In this way, the letter becomes an archive in which hurt is materialized and recorded, as well as in which it is felt, anticipated, and comprehended. Toward the end of the same letter, Bernadette writes:

Then it hits me [the repeated absence of Eugenia's response]. I stop writing you and push it all out of my mind. 2, 3, 4 days go by and I start writing you again. . . . I forget you're not here, are you? Please write.

The letter's ambivalence toward writing her mother interweaves processes of memory and forgetting. This double gesture resonates with Jacques Derrida's (1996) sense that the archive is the site where the past and its claims on the subject are called into question. ${ }^{16}$ Bernadette's writing conveys this sense of uncertainty and traces the trajectory of a return to forgetting that nevertheless becomes the impetus for connection. In this way, Bernadette's letter refracts 
temporally just as Derrida conceives of the archive as containing a link to futurity. For her letter ends with a question - I forget you're not here, are you - and the request for a response-please write.

This question and request have made claims on me. Six years after Bernadette entrusted them to me, the letters remain in my home, transforming it into the place where the Martinez history is housed; that is, into an archive. Multiple copies of each individual letter are stored in folders that hang in a wood filing cabinet. ${ }^{17}$ The placement of the letters in their respective folders is not permanent but changes according to the context in which they are encountered and understood. And this context is shaped more by my ongoing relationship with Bernadette than it is by the documents themselves.

In addition to the letters, hundreds of other documents that broadly relate to them are stored in the filing cabinet's drawers. These include handwritten notes, transcripts, newspaper clippings, visitor applications for the prison, photographs, epidemiological reports, funeral and prayer cards, photocopies of old property deeds, and the like. These documents are like the connective tissues between discursive fields that provide the structure of the archive. They also expand its interpretive and material possibilities.

As for the originals: both the letters and their surviving envelopes are preserved in plastic sleeves bound in heavy, three-ring folders. Currently, the folders sit in a bookshelf positioned beside the filing cabinet. Both the shelf and the cabinet are in view of me as I write this article. There have been times when I have been unable to bear this proximity, which induces a feeling of being observed. More than once, I've had to move to another room, or leave the house altogether, to work in a less encumbered environment.

In The Space of Literature, Maurice Blanchot $(1983,22)$ speaks of an "essential solitude" that accompanies writing. This solitude doesn't refer to the celebrated aloneness that is supposedly necessary for creative composition. Instead, it's characterized by the shadow of infinite thought that encloses the writer. It's also the permanent estrangement of the writer from thought once it's been transfigured as words on a page. The writer's solitude adheres in the work, demanding that "whoever reads it enter into an affirmation of the work's solitude, just as he who writes it belongs to the risk of this solitude." But what is the nature of this risk and what can it tell us about why one writes? Might the risk of the writer's solitude be that it's precisely that which puts him or her in contact with the world? ${ }^{18}$ 
I pull the metal rings of a binder open and slip a letter out of its plastic sleeve. It is thin and wrinkled, torn-edged, yellowed. The letter "pricks me . . . bruises me" like a photograph whose detail stirs personal pain in the viewer (Barthes 1981, 27). It's not just the text but also the image of the text - the uncertain print script, the misspellings, its isolation from the other letters, which seem similarly isolated. Yet the letter functions as "a connector between two distant points, as a bridge" (Altman 1982,13) that plots links between affective and social fields.

I consider taking the letters out of their sleeves, tossing them into the air, letting them fall where they may, just as Bernadette did on that spring afternoon. An intricately entangled web of hurt and hope; a closer approximation, perhaps, to the complicated story the letters weave. But this is not a story of chance. Rather, it's a story of fragmentation and dispersal; and desire for, and impossibility of, cohesion. It's a work about history and memory, separation and return, four female writers seeking to connect disparate events, locations, and lives into a meaningful, albeit incomplete and unfinished, whole.

\begin{abstract}
This article is an ethnographic account of an archive of prison letters written by three generations of female kin. Based on long-term ethnographic research in rural New Mexico, it describes the context in which the letters were written, as well as the desires, preoccupations, and practices that transformed them into an archive. I have placed a particular focus on how dislocation and connection manifest in the letters and shape the kinds of narratives the archive tells. Themes of isolation, loss, and memory are explored within the wider context of colonial history and the acceleration of the carceral state. This article seeks to integrate these registers analytically, while elucidating the role of archiving for a subject's present life. [archive; writing; affect; materiality; prison; feminist historiography]
\end{abstract}

\title{
NOTES
}

Acknowledgments I am deeply grateful to the Martinez family for their engagement with this project and for their continued trust. I benefited greatly from discussion as I presented parts of this article in the "Sensing Precarity" session at the 2011 Annual Meeting of the American Anthropological Association, and in the 2013 seminar "Literary Anthropology" at the School for Advanced Research. I wish to express gratitude to Anne Allison, Lauren Berlant, João Biehl, Michael Jackson, Stefania Pandolfo, Lisa Stevenson, and Kathleen Stewart for their critical insights on different versions of this manuscript. I also thank the anonymous reviewers for their helpful comments and suggestions, and Cymene Howe for her superb editorial work.

1. The authors of the letters have given me permission to study, write about, and quote the letters in this article. They have offered continuous support - sometimes directly, sometimes tangentially - on all aspects of this research, and I attribute any strength of 
this article to their essential role in its development. Any weakness in the article's analysis is my own.

2. The Hispanos of northern New Mexico trace their ancestry to the Spanish colonists. They comprise the majority of the region's population, and the Spanish language is still spoken in many Hispano households.

3. Liz Stanley (2004) provides a helpful discussion of these complex editorial practices when working with the epistolary form.

4. Helen Freshwater $(2003,9)$ describes "the allure of the archive" as, in part, voyeuristic pleasure and, in part, the sense of accessing authentic material: "The archive grounds claims of truth, plausibility, authenticity. For the researcher utilizing archived material, the temptation of making a claim to the academic authority conferred by undertaking 'proper research' may prove irresistible."

5. Valentina Napolitano $(2015,47)$ writes that traces "signal the limits of representation; they are the materials of knots of histories at the margins, as well as auratic presences.” As such, they are significant sites for anthropological study.

6. In 1821, after gaining its independence from Spain, Mexico continued to adhere to the land policies adopted by the former colonial power. These community grants were built on lands used by Native Pueblos at various times and the resulting violence and conflict between Hispanos and Pueblo Indians is deeply embedded, but often overlooked, in New Mexico's land-grant history.

7. As Roxanne Dunbar-Ortiz $(2007,5)$ writes, "Land tenure based on cooperation characterized the poor communities of New Mexico, while individualism and competition for material gain characterized the capitalist mode in the United States."

8. For Lauren Berlant $(2008,4)$, a genre "locates real life in an affective capacity to bracket many kinds of structural and historical antagonisms on behalf of finding a way to connect with the feeling of belonging to a larger world, however aesthetically mediated."

9. It is widely understood that the United States's correctional system assures the maintenance of a growth of prisons and the permanent disenfranchisement of citizens convicted of felony offenses. Instead of preparing prisoners to successfully reenter society, the correctional system's prisons, post-release court-mandated classes, drug screenings, meetings with probation officers and addiction-recovery meetings, among other requirements, prepare parolees for reentry into prison. Indeed, two out of every three prisoners released will be rearrested within two years, and half of those released from prison will be incarcerated again within three years. The vast majority of prisoners are nonviolent drug offenders, primarily African American and Latino, housed in for-profit, privately run prisons; see http://www.sentencingproject.org/issues/incarceration.

10. Between 1980 and 2010, the number of women in U.S. prisons increased an astonishing 648 percent. In New Mexico, women account for more than 10 percent of the total prison population, and their numbers are steadily expanding, while the male inmate population has remained stable.

11. In 2013, the Internal Revenue Service reclassified the Corrections Corporation of America from a standard corporation to a "real estate investment trust," effectively making its inmates "renters" (Popper 2013). This tax-savings scheme is designed to expand socalled growth opportunities in the prison marketplace at a time when incarceration rates are finally declining for the first time in forty years, partly due to problems with overcrowding and an increased awareness of the failure of the War on Drugs.

12. According to a national study of mental illness in the prison population (Glaze and James 2006), 73 percent of women in state prisons, the majority of whom suffer from substance abuse, have at least one mental health problem.

13. I am thinking here of civilizing efforts, be they psychoanalytic or religious, to cultivate the apparent irrationality of the so-called primitive.

14. Although I have juxtaposed them here, the sequence of correspondence is unknown.

15. Alfred Gell's (1998, 221-23) notion of the distributed object is pertinent here. Such an object is created through different temporal and spatial relations and exists in material form and as an idea and an intention. 
16. Jacques Derrida (1996, 11) writes that the archive "will never be either memory or anamnesis as spontaneous, alive and internal experience. On the contrary: the archive takes place at the place of originary and structural breakdown of said memory."

17. Allan Sekula (1986) observes that the filing cabinet constitutes the primary site of archival rationalization. But it's also an artifact itself, and its documents can be mobilized for an endless variety of reasons.

18. For Blanchot (1983), the risk of solitude is not the separation of the writer from the other, but of the self from itself.

\section{REFERENCES}

Altman, Janet Gurkin

1982 Epistolarity: Approaches to a Form. Columbus: Ohio State University Press. Barthes, Roland

1981 Camera Lucida: Reflections on Photography. Translated by Richard Howard. New York: Hill and Wang. Originally published in 1980.

2010 Mourning Diary: October 26, 1977-September 15, 1979. Translated by Richard Belting, Hans

Howard. New York: Hill and Wang. Originally published in 2009.

2011 An Anthropology of Images: Pictures, Medium, Body. Translated by Thomas Dunlap.

Bennett, Jane

Chicago: University of Chicago Press. Originally published in 2001.

2010 Vibrant Matter: A Political Ecology of Things. Durham, N.C.: Duke University Press.

Bennett, Tony

1995 The Birth of the Museum: History, Theory, Politics. New York: Routledge.

Berlant, Lauren

2008 The Female Complaint: The Unfinished Business of Sentimentality in American Culture.

Bernstein, Lee Durham, N.C.: Duke University Press.

2010 America is the Prison: Arts and Politics in Prison in the 1970s. Chapel Hill: University of North Carolina Press.

Biehl, João

2013 "Ethnography in the Way of Theory." Cultural Anthropology 28, no. 4: 573-97. http:/ /dx.doi.org/10.1111/cuan.12028.

Blanchot, Maurice

1983 The Space of Literature. Translated by Ann Smock. Lincoln: University of Nebraska Press. Originally published in 1955.

Burton, Antoinette

2005 Archive Stories: Facts, Fictions, and the Writing of History. Durham, N.C.: Duke University Press.

Chaudhuri, Nupur, Sherry Katz, and Mary Elizabeth Perry, eds.

2010 Contesting Archives: Finding Women in the Sources. Urbana: University of Illinois Press.

Clifford, James, and George E. Marcus, eds.

1986 Writing Culture: The Politics and Poetics of Ethnography. Berkeley: University of California Press.

Dave, Naisargi N.

2012 Queer Activism in India: A Story in the Anthropology of Ethics. Durham, N.C.: Duke University Press.

Derrida, Jacques

1996 Archive Fever: A Freudian Impression. Translated by Eric Prenowitz. Chicago:

Dirks, Nicholas University of Chicago Press. Originally published in 1995.

2002 "Annals of the Archive: Ethnographic Notes on the Sources of History." In From the Margins: Historical Anthropology and its Futures, edited by Brian Keith Axel, 47-65. Durham, N.C.: Duke University Press. 
Dunbar-Ortiz, Roxanne

2007 Roots of Resistance: A History of Land Tenure in New Mexico. Norman: University of Oklahoma Press.

2014 An Indigenous Peoples' History of the United States. Boston: Beacon Press. Eagleton, Terry

1982 The Rape of Clarissa: Writing, Sexuality, and Class Struggle in Samuel Richardson. Oxford: Blackwell.

Edwards, Elizabeth

2001 Raw Histories: Photography, Anthropology, and Museums. New York: Berg. Espinoza-Herold, Marielle

2007 "Stepping beyond Sí Se Puede: Dichos as a Cultural Resource in Mother-Daughter Interaction in a Latino Family." Anthropology and Education Quarterly 38, no. 3: Foucault, Michel 260-77. http://dx.doi.org/10.1525/aeq.2007.38.3.260.

1979 Discipline and Punish: The Birth of the Prison. Translated by Alan Sheridan. New York: Vintage. Originally published in 1975.

2002 Archaeology of Knowledge. Translated by A. M. Sheridan-Smith. New York: Routledge. Originally published in 1969.

Freshwater, Helen

2003 “The Allure of the Archive.” Poetics Today 24, no. 4: 729-58. http://dx.doi.org/ 10.1215/03335372-24-4-729.

Garcia, Angela

2010 The Pastoral Clinic: Addiction and Dispossession along the Rio Grande. Berkeley: University of California Press.

2014 "Regeneration: Love, Drugs, and the Remaking of Hispano Inheritance." Social Anthropology 22, no. 2: 200-12. http://dx.doi.org/10.1111/1469-8676.12070.

Gell, Alfred

1998 Art and Agency: An Anthropological Theory. Oxford: Clarendon.

Glaze, Lauren E., and Doris J. James

2006 "Mental Health Problems of Prison and Jail Inmates." Special report, Bureau of Justice Statistics. Washington, D.C.: Department of Justice. http://www.bjs. gov/index.cfm?ty=pbdetail\&iid $=789$.

González Echevarria, Roberto

1990 Myth and Archive: A Theory of Latin American Narrative. New York: Cambridge

Hemmings, Clare University Press.

2011 Why Stories Matter: The Political Grammar of Feminist Theory. Durham, N.C.: Duke University Press.

Hull, Matthew S.

2012 "Documents and Bureaucracy." Annual Review of Anthropology 41: 251-67. http: / /dx.doi.org/10.1146/annurev.anthro.012809.104953.

Jacobi, Tobi, and Ann Folwell Stanford

2014 Women, Writing, Prison: Activists, Scholars, and Writers Speak Out. Lanham, Md.: Rowan and Littlefield.

Joyce, Patrick

1999 “The Politics of the Liberal Archive." History of the Human Sciences 12, no. 2: 3549. http://dx.doi.org/10.1177/09526959922120234.

Kristeva, Julia

1987 Tales of Love. Translated by Leon S. Roudiez. New York: Columbia University

Mbembe, Achille Press. Originally published in 1983.

2002 "The Power of the Archive and its Limits." In Refiguring the Archive, edited by Carolyn Hamilton, Verne Harris, Jane Taylor, Michele Pickover, Graeme Reid, and Razia Saleh, 19-26. Dordrecht, Netherlands: Kluwer Academic Publishers. 
Montoya, Maria E.

2002 Translating Property: The Maxwell Land Grant and the Conflict over Land in the American West, 1840-1900. Berkeley: University of California Press.

Napolitano, Valentina

2015 “Anthropology and Traces." Anthropological Theory 15, no. 1: 47-67. http:// dx.doi.org/10.1177/1463499614554239.

Pinney, Christopher

2001 "Piercing the Skin of the Idol." In Beyond Aesthetics: Art and the Technologies of Enchantment, edited by Christopher Pinney and Nicholas Thomas, 157-79. New York: Berg.

Popper, Nathaniel

2013 "Restyled as Real Estate Trusts, Varied Businesses Avoid Taxes.” New York Times, April 21. http://www.nytimes.com/2013/04/22/business/restyled-as-realestate-trusts-varied-businesses-avoid-taxes.html.

Povinelli, Elizabeth A.

2011 "The Woman on the Other Side of the Wall: Archiving the Otherwise in Postcolonial Digital Archives." differences 22, no. 1: 146-71. http://dx.doi.org/ 10.1215/10407391-1218274.

Rhodes, Lorna A.

2001 “Toward an Anthropology of Prisons.” Annual Review of Anthropology 30: 65-83. http://dx.doi.org/10.1146/annurev.anthro.30.1.65.

Sekula, Allan

1986 “The Body and the Archive." October 39: 3-64. http://dx.doi.org/10.2307/ 778312 .

Stanley, Liz

2004 “The Epistolarium: On Theorizing Letters and Correspondences." Auto/Biography 12, no. 3: 201-35. http://dx.doi.org/10.1191/0967550704ab014oa.

Steedman, Caroline

1998 "The Space of Memory: In an Archive." History of the Human Sciences 11, no. 4: 65-83. http: / /dx.doi.org/10.1177/095269519801100405.

2002 Dust: The Archive and Cultural History. New Brunswick, N.J.: Rutgers University Press.

Stevenson, Lisa

2013 Life Beside Itself: Imagining Care in the Canadian Arctic. Berkeley: University of California Press.

Stewart, Kathleen

1996 A Space on the Side of the Road: Cultural Poetics in an "Other" America. Princeton, N.J.: Princeton University Press.

2012 “Precarity’s Forms.” Cultural Anthropology 27, no. 3: 518-25. http://dx.doi.org/ 10.1111/j.1548-1360.2012.01157.x.

Stoler, Ann Laura

2009 Along the Archival Grain: Epistemic Anxieties and Colonial Common Sense. Princeton, N.J.: Princeton University Press.

Stoller, Paul

2015 “The Bureau of Memories: Archives and Ephemera." Visual and New Media Review, Cultural Anthropology website, March 20. https://culanth.org/ fieldsights / 647-the-bureau-of-memories-archives-and-ephemera.

Taylor, Diane

2003 The Archive and the Repertoire: Performing Cultural Memory in the Americas. Durham,

Thompson, E. P. N.C.: Duke University Press.

1966 The Making of the English Working Class. New York: Vantage. Zeitlyn, David

2012 "Anthropology in and of the Archives: Possible Futures and Contingent Pasts. Archives as Anthropological Surrogates.” Annual Review of Anthropology 41: 46180. http://dx.doi.org/10.1146/annurev-anthro-092611-145721. 